\title{
Storytelling method using big book to improve children's listening skill
}

\author{
Sri Wahyuni, Suharni, Retanida \\ Faculty of Education Science, Universitas Lancang Kuning, Indonesia \\ E-mail: sriwahyuni91@unilak.ac.id
}

\author{
Article History \\ Submitted: February 2, 2020 \\ Accepted: April 30, 2020 \\ Published: Mei 2, 2020 \\ DOI: $10.26555 /$ jecce.v3i1.1692
}

\begin{abstract}
The low of listen ability in children aged 5-6 years is the background of this action research, so this research aims to improve these abilities. One method that has proven to be effective solve that problem is the method of storytelling with a big book. Data on classroom action research was collected using observation techniques and analyzed in quantitative descriptive. This study involved ten students as participants. The result of the study showed that storytelling with a big book can improve the listening skill of 5-6 years old children in PAUD Bintang Mutiara, Pekanbaru. Before applying storytelling method with big book, the participants' listening skill was categorized as 'has not been developed". After applying the storytelling method with big book, their listening skill was categorized as "Developed as expected" with a score of $71.67 \%$. The improvement of participants' listening skill from 'pre-cycle' to 'cycle 1 ' was $21 \%$. From cycle I to cycle II, their listening skill was improved by $64 \%$. From pre-cycle to cycle II, the improvement was $89 \%$. Overall, the improvement of listening skills was $75.56 \%$.
\end{abstract}

Keywords : big book, listening skills, storytelling method.

Abstrak
Rendahnya kemampuan menyimak anak usia 5-6 tahun
melatarbelakangi penelitian tindakan ini, sehingga penelitian ini
bertujuan untuk meningkatkan kemampuan tersebut. Salah satu
metode yang terbukti efektif adalah metode bercerita dengan big book.
Data pada penelitian tindakan kelas dikumpulkan menggunakan teknik
observasi dan dianalisis secara kuantitatif deskriptif. Subjek penelitian
adalah kelas B (N=10). Hasil penelitian ini menunjukkan bahwa metode
bercerita dengan big book dapat meningkatkan kemampuan menyimak
anak usia 5-6 tahun di PAUD Bintang Mutiara Kota Pekanbaru. Sebelum
menerapkan metode bercerita dengan big book berada pada kategori
Belum Berkembang dan setelah diadakan metode bercerita dengan big
book mencapai kategori Berkembang Sesuai Harapan yakni 71,67\%,
Besarnya peningkatan kemampuan menyimak pra siklus ke siklus I
peningkatan sebesar 21\%. Sedangkan peningkatan kemampuan
menyimak dari siklus I ke siklus II sebesar 64\%, dan peningkatan dari
pra siklus ke siklus II sebesar 89\%, secara keseluruhan peningkatan
kemampuan menyimak melalui metode bercerita dengan big book
yakni sebesar 75,56\%.

Kata Kunci : big book, kemampuan menyimak, metode bercerita. 


\section{INTRODUCTION}

Listening skill is important for human. Many knowledge and experiences are obtained from listening activities. We spend most of our daily life by listening. Listening is an inseparable activity of human life's aspect (Ridyawati, 2015). Considering that children build their cognitive foundation during their childhood, it is important to teach them listening skill in ECE level.

This skill plays important role in developing children's linguistic aspects. In language aspect, this skill is a part of receptive language. Children's good receptive language development will support their expressive language development. Expressive language can be improved through various methods, one of them is role play (Yuniati \& Rohmadheny, 2020). However, the development of expressive language requires support from receptive language. Therefore, its development, especially listening, should gain teacher's serious attention.

Some cases show that children's listening skill needs improvement. Based on the result of observation conducted in PAUD Bintang Mutiara Pekanbaru, some phenomena relating to children's listening skill were discovered. Majority of students lacked understanding of instruction within a story (e.g., instruction to follow examples of characters of figure in the story). Besides, they also had not been able to repeat a complex sentence in a story, which is shown by their confusion when expressing and repeating a sentence. The observation result also shows that they cannot understand rules of a game properly. They also stated that they did not like the story, making them not to pay attention when teachers read them a story. The result of the observation indicates children's low level of listening skill.

Listening skill is important for learning activities, with good listening skill, children may find it easier to understand the topics being discussed in the learning activities. A proper, suitable learning method also emerges as important part to develop good listening skill. Therefore, teachers need to perform actions to improve students' language development, especially listening skill. A range of strategies can be applied to improve children's listening skill, one of them is storytelling using big book.

Storytelling with big book may influence children's listening skill (Imroatun, 2017). Storytelling serves as the method, while big bog serves as the media. As a method, storytelling refers to an activity done by an individual to deliver a message, information, or a story verbally 
or written (Habsari, 2017). Big book is a learning material that also functions as a learning approach because its user needs certain approach to use it (Nurlaili, 2018). Storytelling with big book serves as a method that makes children listening to the teacher's story through big pictures in book shown in accordance with the teacher's story. Using this method, children's listening skill can be improved. The present classroom action research is conducted to prove the effectiveness of storytelling with big book in improving preschool-aged children's listening skill.

\section{METHOD}

The present study was categorized as Classroom Action Research. This study consisted of two cycles, which were done in accordance with Eliot (Mulyasa, 2013) as follow: (a) Planning Stage: In this stage, the plan to improve children's listening skill was designed. Determining the class to be involved in the study (i.e., PAUD Bintang Mutiara Pekanbaru). Setting the schedule of the study (i.e., July 2018). Preparing the lesson plan. Preparing observation sheet for teachers, children, and learning media. (b) Action Stage: The treatment was given three times a week in accordance with the learning subtheme in that week. Each cycle of the study consisted of three meetings. The study was conducted during odd semester of 2018/2019 academic year. The treatments were described in Table 1 below.

Table 2.1. Storytelling Activities Using Bigbook Media in Cycle I and Cycle II

\begin{tabular}{lll}
\hline No & \multicolumn{1}{c}{ Cycle I } & \multicolumn{1}{c}{ Activity } \\
\hline 1 & First Meeting & Telling Story of "Bintang Anjing Sang Penjaga Rumah" \\
\hline 2 & Second meeting & Telling story about "Kancil yang Cerdik" \\
\hline 3 & Third Meeting & Telling story about "Kucing yang Baik Hati" \\
\hline No & Cycle II & \multicolumn{1}{c}{ Activity } \\
\hline 1 & First Meeting & Telling story about "Anjing Hewan Peliharaan" \\
\hline 2 & Second meeting & Telling story about Kerajaan Binatang Bintang Laut" \\
\hline 3 & Third Meeting & Telling story about "Burung Kakak Tua" \\
\hline
\end{tabular}

(c) Observation stage: The teachers observed the storytelling with big book and assessed the children who did the activities in accordance with the purpose of the use of the method. (d) Reflection stage: In this stage, the teachers write down the observation result, evaluate and analyze the result of activity, and improve the weaknesses or mistakes for the next learning activity. 
The participants of the study were ten 5-6 years-old children in PAUD Bintang Mutiara Pekanbaru, consisting of 5 male and 5 female children. The study was conducted in PAUD Bintang Mutiara Pekanbaru in August 2018. The data were collected using observation. To describe the data on teachers' and children's activities during the learning process, the following formula was applied.

$$
p=\frac{\mathrm{F}}{\mathrm{N}} \times 100 \%
$$

\section{Description:}

$$
\begin{array}{ll}
\mathrm{f} & =\text { frequency } \\
\mathrm{N} & =\text { number of individuals } \\
\mathrm{P} & =\text { percentage } \\
100 \% & =\text { fixed number }
\end{array}
$$

The criteria $f$ the percentage areas follow

Table 2.2. Criteria of Teacher's Activity Assessment

\begin{tabular}{cll}
\hline No & Percentage & Description \\
\hline 1 & $76 \%-100 \%$ & Good \\
\hline 2 & $56 \%-75 \%$ & Fair \\
\hline 3 & $0 \%-55 \%$ & Bad \\
\hline
\end{tabular}

Percentage formula was used to determine the improvement of children's listening skill.

$$
P=\frac{\text { Postrate }- \text { Baserate }}{\text { Baserate }} \times 100 \%
$$

\section{Description:}

$\mathrm{P} \quad$ = improvement percentage

Posrate $\quad=$ Score after the treatment is given

Baserate $=$ Score before the treatment is given

$100 \%=$ fixed number

In determining the criteria, four categories were made, they were 'Not Yet Developed", "Begin to Develop", "Well Developed", "Developed as Expected". The percentage of these criteria was as follow.

Table 2.3. Assessment Criteria of Children's Listening Skill and Activity

\begin{tabular}{ccc}
\hline No & Percentage & Description \\
\hline 1 & $76 \%-100 \%$ & Well-developed \\
\hline
\end{tabular}




\begin{tabular}{lll}
\hline 2 & $56 \%-75 \%$ & Developed as Expected \\
\hline 3 & $40 \%-55 \%$ & Begin to Develop \\
\hline 4 & $0 \%-39 \%$ & Not Yet Developed \\
\hline
\end{tabular}

Action research is deemed success if the average score reach $70 \%$, however, it will be better if it reaches $80 \%$. In other words, the treatments are deemed success if the children's listening skill reaches an average score of $70 \%$.

\section{RESULT AND DISCUSSION}

The present study was conducted in four stages, namely planning, action, observation, and reflection stage. In the first stage, the plan was designed. It deals with the activities to be done by the teacher in the action stage. In the second stage (i.e., action stage), the plan that has been designed was implemented. In the third stage, the teacher observed the process and view the children's way of listening by applying storytelling method with big book. The teacher also compared the activity 1 and 2 of cycle I and II. In the fourth stage, the teacher reviewed the activities, finding out the strengths and weaknesses of the implementation of storytelling big book. The result of this stage was used as a basis for improvement in the next cycle.

The next step is to seek and develop improvement by reviewing theory, conducting discussion with peers or expert, and exploring personal experience.

Table 4.1. Recapitulation of Listening Skill in Pre-cycle, Cycle I, and Cycle II

\begin{tabular}{|c|c|c|c|c|c|c|}
\hline No & Indicator & Pre-cycle & Cycle I & Cycle II & Average & Desc. \\
\hline 1 & $\begin{array}{l}\text { Understanding } \\
\text { some instructions } \\
\text { simultaneously }\end{array}$ & 35.00 & 45.00 & 73.33 & 76.67 & $\begin{array}{c}\text { Well- } \\
\text { developed }\end{array}$ \\
\hline 2 & $\begin{array}{l}\text { Repeating more } \\
\text { complex sentences }\end{array}$ & 32.50 & 40.83 & 76.67 & 75.00 & $\begin{array}{c}\text { Developed } \\
\text { as } \\
\text { Expected } \\
\end{array}$ \\
\hline 3 & $\begin{array}{l}\text { Understanding } \\
\text { rules of a game }\end{array}$ & 40.00 & 45.00 & 65.00 & 75.00 & $\begin{array}{c}\text { Developed } \\
\text { as } \\
\text { Expected } \\
\end{array}$ \\
\hline & Total & 107 & 130 & 215 & 226 & \\
\hline & Average & 35.8 & 43.6 & 71.7 & 75.56 & \\
\hline & Criteria & $\begin{array}{c}\text { Not Yet } \\
\text { Developed }\end{array}$ & $\begin{array}{l}\text { Begin to } \\
\text { Develop }\end{array}$ & $\begin{array}{c}\text { Well- } \\
\text { developed }\end{array}$ & $\begin{array}{l}\text { Developed } \\
\text { as } \\
\text { Expected }\end{array}$ & \\
\hline
\end{tabular}




\section{Source: 2018 Data processing}

As shown in the table above, children's listening skill during pre-cycle was $35.83 \%$, which was categorized as 'Not Yet Developed'. In cycle I, the score of their listening skill was 43.61\%, which was categorized as 'Begin to Develop', and in cycle II, the score was $71.67 \%$, which was categorized as 'Developed as Expected". The data showed that the improvement occurred in each cycle.

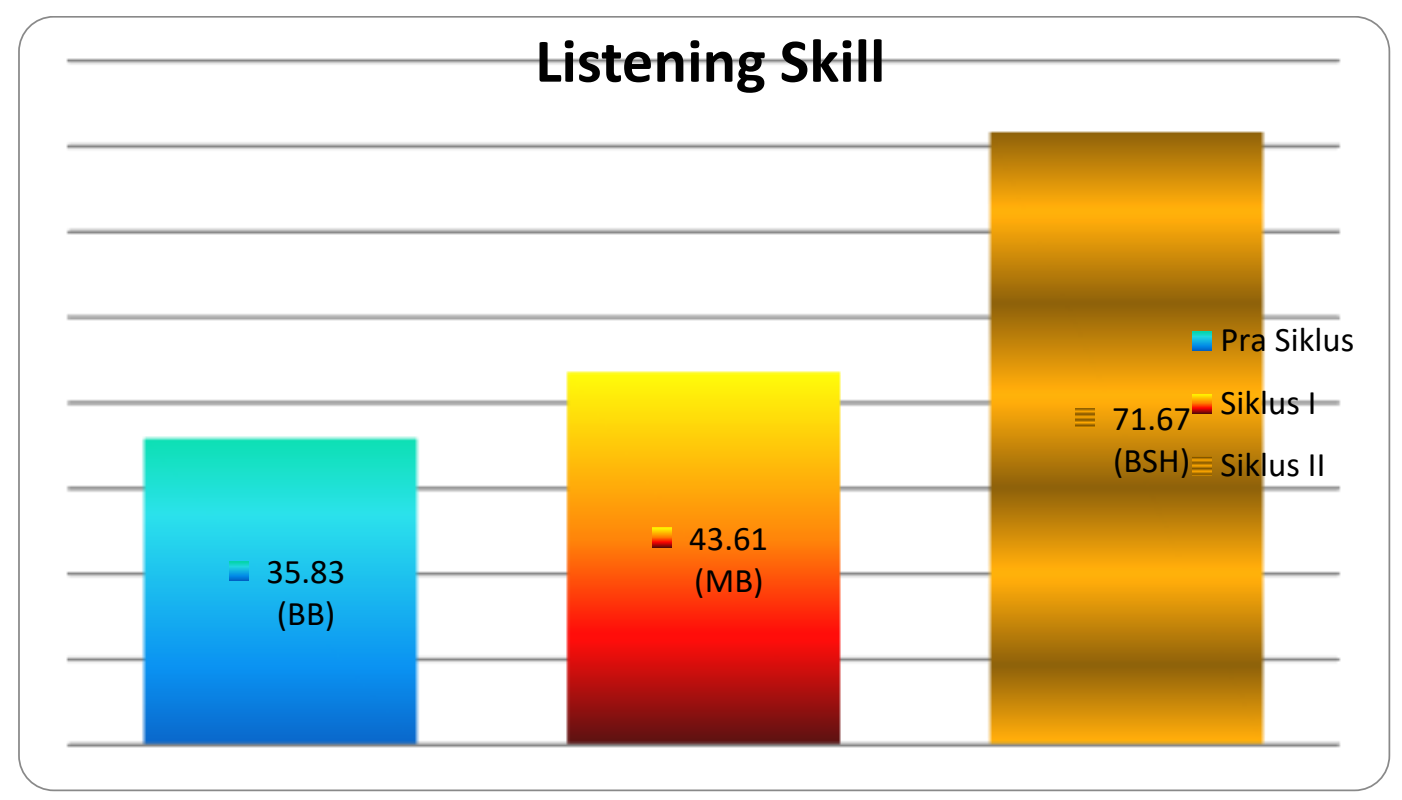

Figure 4.1. Hypothesis Testing on the Improvement of Children's Listening Skill

Since the average score of children's listening skill is greater than $70 \%$, it can be said that this action research succeeded. In other words, storytelling with big book can improve children's listening skill.

The increase in teacher activity is relevant with the children activity. In general, the learning activities in meeting 2 cycle II had been done well. This result showed that teachers also enjoy applying storytelling with big book. This result of research finding, which shows that teachers view big book as a helpful learning media (Kiromi \& Fauziah, 2016). It is also in line with (Imroatun, 2017) who states that big book is one of the alternative media for teacher to improve the students' reading skill. This is shown by the improvement that occurred in each activity. It is shown in Table 4.2 . 
Table 4.2. Children's Activities in PAUD Bintang Mutiara Pekanbaru

\begin{tabular}{|c|c|c|c|c|c|}
\hline No & Children's activity & Cycle I & Cycle II & Average & Desc. \\
\hline 1 & $\begin{array}{l}\text { Children give answers about } \\
\text { possible story line based on } \\
\text { picture shown by the teacher. }\end{array}$ & 63.33 & 81.11 & 72.22 & Fair \\
\hline 2 & $\begin{array}{l}\text { Children listen to teachers who } \\
\text { read a story }\end{array}$ & 58.89 & 82.22 & 70.56 & Fair \\
\hline 3 & $\begin{array}{l}\text { Children give comments about } \\
\text { words in the story. }\end{array}$ & 62.22 & 78.89 & 70.56 & Fair \\
\hline 4 & $\begin{array}{l}\text { Children give answer about the } \\
\text { most favorite part of the story }\end{array}$ & 62.22 & 85.56 & 73.89 & Fair \\
\hline 5 & Children pay attention to the text. & 53.33 & 74.44 & 63.89 & Fair \\
\hline & Total & 300.00 & 402.22 & 351.11 & \\
\hline & Average & 60.00 & 80.44 & 70.22 & \\
\hline & Criteria & Fair & Good & Fair & \\
\hline
\end{tabular}

\section{Source: 2018 Data processing}

As shown in table above the mean score of children's activity in cycle I was $60.00 \%$, which was categorized as 'fair', and in cycle II, the mean score was $80.44 \%$, which was categorized as 'good'. Overall, the score of children's activity was $70.22 \%$ and was categorized as 'fair'.

The observation result shows that in pre cycle, the average score was 35.83 , while in cycle I, the average score was 43.61 . The result of analysis showed a $21 \%$ increase from precycle to cycle I. The observation result shows that in cycle I, the average score was 43.61 , while in cycle II, the average score was 71.67. The observation result shows that in pre cycle, the average score was 35.83, while in cycle II, the average score was 71.67 .

Based on the improvement that occurs in every meeting, it can be said that storytelling with big book can improve 5-6 years old children's listening skill. It is shown in the following figure. 


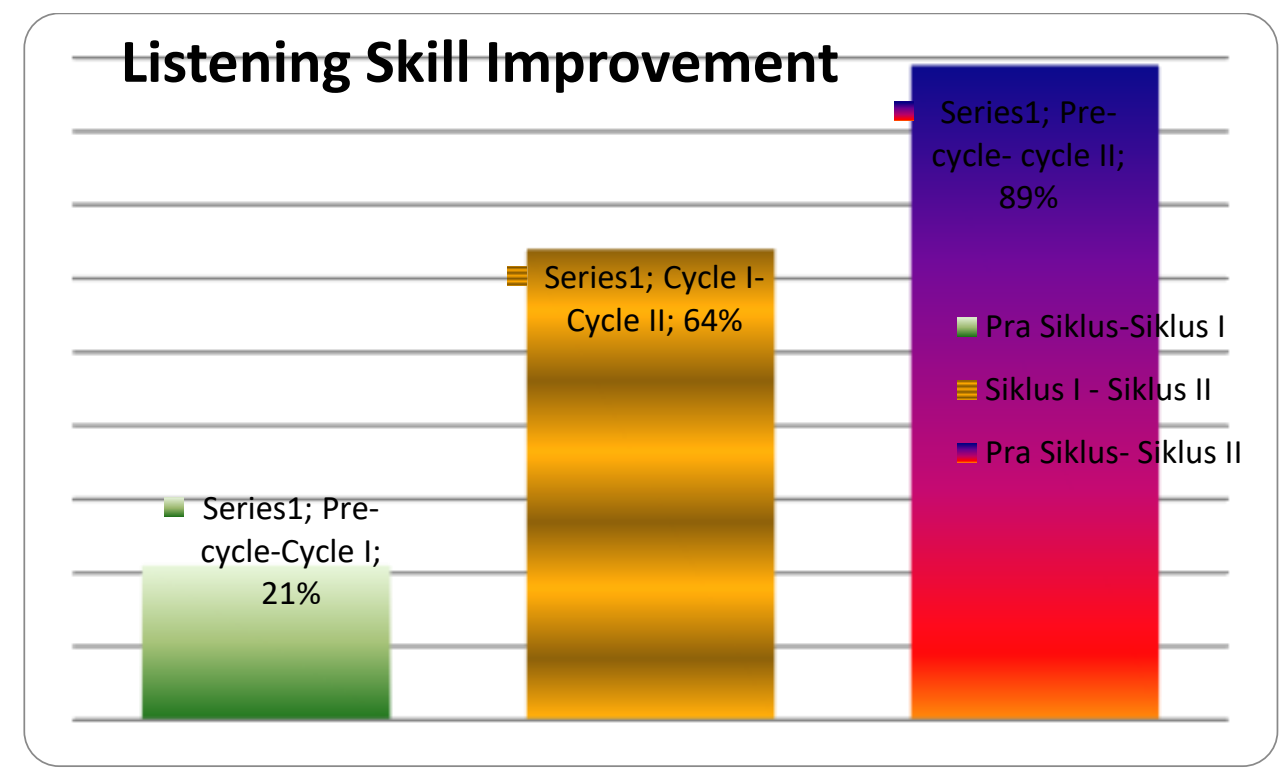

Figure 2. Hypothesis Testing on the Improvement of Children's Listening Skill

As shown in Figure 2, there was a $21 \%$ improvement between pre-cycle and cycle I, which was categorized as 'Not yet Developed', while from cycle I to cycle II, the score was $64 \%$, which was categorized as 'Developed as expected'. Further, from pre-cycle to cycle II, the improvement was $89 \%$, which was categorized 'well-developed'. The previous study found that storytelling can improve children's listening skill. This is supported by the finding of the present study which shows there is an improvement in children's listening skill. In other words, storytelling is suitable to improve children's listening skill (Nurhayani, 2010).

In cycle I, children's listening skill was improved, the average score was $43.61 \%$ and was categorized as "begin to develop", this improvement was also followed by the increase in teacher's activity (mean score $=51.11 \%$ ) and children's activity (mean score $=60 \%)$. This result showed that children's listening skill was improved after storytelling method with big book was applied.

This is relevant with statment that storytelling is an activity of delivering information about value or cultural tradition to children both verbally or in writing in order to develop social skill, reading skill, and understanding of knowledge through experience (Aprianti et al., 2016; Gusal, 2017; Ramdhani et al., 2019). This is asserted by (Septiyani \& Kurniah, 2017) who states that story can affects children's mindset and behavior because they like to listen to it. 
Furthermore, when teachers use big book as the media to tell the story, children's listening skill may be affected because they pay attention to the story and the picture in big book.

Teachers should be creative and innovative in developing children's six developmental aspects, especially language development, namely speaking and listening skill. In addition to big book, there are many other media that can be used to enhance children's speaking and listening skill, one of them is video (Azizah, 2018). In addition, the result of the study shown that role play can be used as a method to improve children's social and speaking skill (Siska, 2011). Another study that serial picture can stimulate students' thought, improving their speaking skill (Aprinawati, 2017). From the result of the studies described above, it could be concluded that children's listening skill can be improved through big book, among other media.

Storytelling method can affect children's development of expressive or receptive language (Anggraeni et al., 2019). This is in line with (Yarger, 2006) who states that storytelling with big book can better affect children's listening skill. In the present study, cycle II exhibited greater improvement than cycle I did (i.e 71.67\%). This improvement may be affected by the increase in teacher's and children's activity (i.e., $80 \%$ and $80,44 \%$, respectively), which was categorized as 'good'. This result of study found that storytelling with simple story book can improve children's listening skill (Widayati \& Simatupang, 2019). It indicates that applying storytelling method with big book makes children find it easier to improve their listening skill.

Story is useful for achieving the purpose of early childhood education purpose since children like to listen to story, they view it as a fun activity (Ningsih, 2013). The result of the study shows that teacher can use storytelling activity to internalize honesty, bravery, loyalty, and other positive attitudes in family, school, and community lives (Khotijah, 2016). Besides, storytelling also brings social knowledge, moral, and religious values. (Zaman et al., 2010). Storytelling method can be used to provide information regarding children's social life and their surrounding people with various occupations (Setiantono, 2012). Further, storytelling method helps children build various roles they may choose and various services they want to give to the community (Guido et al., 2015). 
As a learning media, big book can also be adjusted to local wisdom. Stories in big book can be adjusted to values of local culture. Putting local stories into big book makes it more interesting, as proven by (Falah, 2018) who developed a big book using Javanese language.

In this study, there was a $21 \%$ improvement of children's listening skill from pre-cycle to cycle I. From cycle I to cycle II, there was $64 \%$ improvement, while from pre-cycle to cycle II, there was $89 \%$ improvement. This result indicated that the children's listening skill was improved in each cycle when storytelling with big book was applied. In other words, storytelling can be used as one of activities to improve children's listening skill because they view it as a fun activity. Besides, storytelling with big book may influence children's listening skill.

\section{CONCLUSION}

The present study concludes that storytelling method with big book can improve children's listening skill. Based on the discussion between the researchers and the observer, the teacher has delivered the material systematically and use the time efficiently. Besides, the teacher is also able to depict the relationships among the content. The teacher's control was improved, causing children to be more serious in learning activities. Initially, the children can only listen to the story, but now they are able to listen and retell the story. The children's listening skill was improved by $21 \%$ in pre-cycle to cycle I. From cycle I to cycle II, their listening skill was improved by $64 \%$. From pre-cycle to cycle II, the improvement was $89 \%$. Overall, the improvement of listening skill was $75.56 \%$.

\section{REFERENCES}

Anggraeni, D., Hartati, S., \& Nurani, Y. (2019). Implementasi metode bercerita dan harga diri dalam meningkatkan kemampuan berbicara anak usia dini. Jurnal Obsesi: Jurnal Pendidikan Anak Usia Dini. https://doi.org/10.31004/obsesi.v3i2.224

Aprianti, W., Gunatama, G., \& Indriani, M. S. (2016). Analisis fakta dan sarana cerita dalam teks nilai moral fabel siswa Kelas VIII A1 di SMP Negeri 1 Singaraja. Jurnal Pendidikan Bahasa Dan Sastra Indonesia Undiksha, 3(1). 
Aprinawati, I. (2017). Penggunaan media gambar seri untuk meningkatkan kemampuan berbicara anak usia dini. Jurnal Obsesi: Journal of Early Childhood Education. https://doi.org/10.31004/obsesi.v1i1.68

Azizah, E. N. (2018). Pengaruh video cerita ipin dan upin terhadap kemampuan menyimak dan berbicara pada anak Taman Kanak-Kanak Kelompok A Kecamatan Ngawi Kabupaten Ngawi. Raudhatul Athfal: Jurnal Pendidikan Islam Anak Usia Dini. https://doi.org/10.19109/ra.v2i2.2845

Falah, F. (2018). Pengembangan media big book berbahasa Jawa babasan Banten bagi anak usia 5-6 tahun (Pengembangan Model di PAUD Taman Yunior, Kota Cilegon, Banten). Jurnal Penelitian Dan Pengembangan Pendidikan Anak Usia Dini. https://doi.org/10.30870/jpppaud.v5i2.4698

Guido, D., Morandi, G., Palluzzi, F., \& Borroni, B. (2015). Telling the story of frontotemporal dementia by bibliometric analysis. In Journal of Alzheimer's Disease. https://doi.org/10.3233/JAD-150275

Gusal, L. O. (2017). Nilai-nilai pendidikan dalam cerita rakyat Sulawesi Tenggara karya La Ode Sidu. Jurnal Humanika, 3(15).

Habsari, Z. (2017). Dongeng sebagai pembentuk karakter anak. BIBLIOTIKA: Jurnal Kajian Perpustakaan Dan Informasi. https://doi.org/10.17977/um008v1i12017p021

Imroatun, I. (2017). Media belajar bigbook bagi pengembangan baca nyaring anak usia dini. Prosiding Seminar Nasional Pembelajaran Baca, Tulis, Dan Hitung Tingkat Permulaan Bagi Anak Usia Dini.

Khotijah. (2016). Strategi pengembangan bahasa pada anak usia dini. Elementary.

Kiromi, I. H., \& Fauziah, P. Y. (2016). Pengembangan media pembelajaran big book untuk pembentukan karakter anak usia dini. Jurnal Pendidikan Dan Pemberdayaan Masyarakat. https://doi.org/10.21831/jppm.v3i1.5594

Mulyasa, E. (2013). Standar kompetensi dan sertifikasi guru. In Standar Kompetensi dan Sertifikasi Guru. 
Ningsih, S. (2013). Peningkatan keterampilan berbicara melalui metode bercerita siswa kelas III SD Negeri 1 Beringin Jaya Kecamatan Bumi Raya Kabupaten Morowali. Jurnal Kreatif Tadulako Online.

Nurhayani, I. (2010). Pengaruh penggunaan metode bercerita terhadap kemampuan menyimak siswa pada mata pelajaran Bahasa Indonesia (Deskriptif analisis di SDN Cimurah I Kecamatan Karangpawitan). Jurnal Fakultas Pendidikan Islam Dan Keguruan Universitas Garut.

Nurlaili, N. (2018). Sumber belajar dan alat permainan untuk pendidikan anak usia dini. Al Fitrah: Journal of Early Childhood Islamic Education. https://doi.org/10.29300/alfitrah.v2i1.1518

Ramdhani, S., Yuliastri, N. A., Sari, S. D., \& Hasriah, S. (2019). Penanaman nilai-nilai karakter melalui kegiatan storytelling dengan menggunakan cerita rakyat Sasak pada anak usia dini. Jurnal Obsesi: Jurnal Pendidikan Anak Usia Dini, 3(1), 153-160.

Ridyawati, R. J. (2015). Peningkatan keterampilan menyimak cerita melalui media VCD film kartun. Jurnal Pendidikan Guru Pendidikan Anak Usia Dini, 4(1).

Septiyani, S., \& Kurniah, N. (2017). Pengaruh media big book terhadap kemampuan berbicara pada anak usia dini. Jurnal Potensia.

Setiantono, T. (2012). Penggunaan metode bercerita bagi anak usia dini di PAUD Smart Little Cilame Indah Bandung. Jurnal EMPOWERMENT.

Siska, Y. (2011). Penerapan metode bermain peran (role playing) dalam meningkatkan keterampilan sosial dan keterampilan berbicara anak usia dini. Procedia - Social and Behavioral Sciences. https://doi.org/10.31289/jppuma.v1i1.548

Widayati, S., \& Simatupang, N. D. (2019). Kegiatan bercerita dengan menggunakan buku cerita sederhana untuk meningkatkan kemampuan menyimak anak. Preschool (Jurnal Perkembangan Dan Pendidikan Anak Usia Dini), 1(1). 
Yarger, H. R. (2006). Strategic theory for the 21st century: the little book on big strategy. In Strategy.

Yuniati, S., \& Rohmadheny, P. S. (2020). Bermain peran: Sebuah metode untuk meningkatkan kemampuan bahasa ekspresif anak. Jurnal Obsesi: Jurnal Pendidikan Anak Usia Dini, 5(1), 60-69-69. https://doi.org/10.31004/obsesi.v5i1.509

Zaman, B., Pd, M., \& Eliyawati, H. C. (2010). Media pembelajaran anak usia dini. In Media Pembelajaran Anak Usia Dini. 